\title{
Putting the Correct "Spin" on Lucas
}

Richard J. Lazarus

Georgetown University Law Center, lazarusr@law.georgetown.edu

This paper can be downloaded free of charge from:

https://scholarship.law.georgetown.edu/facpub/155

45 Stan. L. Rev. 1411-1432 (1993)

This open-access article is brought to you by the Georgetown Law Library. Posted with permission of the author. Follow this and additional works at: https://scholarship.law.georgetown.edu/facpub

Part of the Administrative Law Commons, and the Environmental Law Commons 


\title{
GEORGETOWN LAW Faculty Publications
}

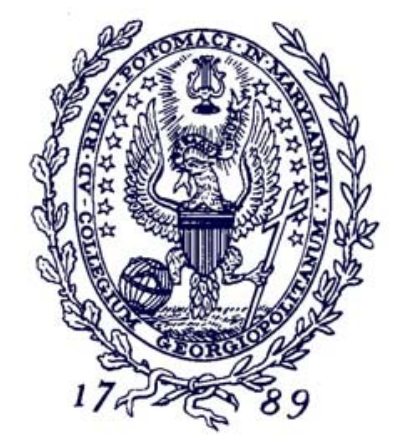

January 2010

\section{Putting the Correct "Spin" on Lucas}

\author{
45 Stan. L. Rev. 1411-1432 (1993) \\ Richard J. Lazarus \\ Professor of Law \\ Georgetown University Law Center \\ lazarusr@law.georgetown.edu
}

This paper can be downloaded without charge from:

Scholarly Commons: http://scholarship.law.georgetown.edu/facpub/155/ 


\title{
Putting the Correct "Spin" on Lucas
}

\author{
Richard J. Lazarus*
}

The Supreme Court decided Lucas v. South Carolina Coastal Council ${ }^{1}$ on the last day of the October 1991 Term, the same day it decided Planned Parenthood v. Casey. ${ }^{2}$ Court watchers had anxiously anticipated what most thought would be two landmark decisions: Casey was expected to strip abortion of its constitutional protection, while Lucas threatened to impose huge financial liabilities on governments that propagate environmental regulations violating the Fifth Amendment's ban on takings of private property without "just compensation." 3 Reactions to the two rulings, juxtaposed against one another, verged on the comical. In less time than it took to read either opinion, pro-choice organizations condemned a decision that was in fact better than most had anticipated, ${ }^{4}$ and environmentalists declared victory based on an opinion that appeared more troubling than expected to those interested in takings issues. ${ }^{5}$ Although taking opposite stands with respect to their relative success, both groups were applying the lessons of political campaign "spin doctors" to the interpretation of Supreme Court rulings.

Pro-choice advocates had concluded prior to Casey that, ironically, they could best realize their objectives through a major Supreme Court loss

* Professor of Law, Washington University in St. Louis. I represented the South Carolina Coastal Council before the United States Supreme Court in the case that is the focus of this essay, Lucas v. South Carolina Coastal Council, 112 S. Ct. 2886 (1992), and previously served as an Assistant to the Solicitor General in the United States Department of Justice from 1986 to 1989. I represented the United States before the Supreme Court in several of the cases discussed in the essay, including Agins v. City of Tiburon, 447 U.S. 255 (1980), San Diego Gas \& Electric Co. v. City of San Diego, 450 U.S. 621 (1981), and Nollan v. California Coastal Commission, 483 U.S. 825 (1987). The analysis contained herein is strictly my own and is not necessarily the same as that of the United States, the Office of the Solicitor General, or the South Carolina Coastal Council. Thanks are owed to Fred Bosselman, John Drobak, Dan Keating, Dan Mandelker, Linda Malone, and Dan Tarlock for commenting on an earlier version of this paper, and to Patricia Verga for valuable research assistance.

1. 112 S. Ct. 2886 (1992).

2. 112 S. Ct. 2791 (1992).

3. U.S. CoNST. amend. V.

4. See, e.g., Tamar Lewin, Long Battles Over Abortion Are Seen, N.Y. TIMES, June 30, 1992, at A18 ("The Pennsylvania decision is a disaster ...." ") (quoting Kate Michelman, president of the National Abortion Rights Action League).

5. See, e.g., Lucas IV: Reaction from Enviros, GREENWIRE, June 30, 1992, available in LEXIS, Nexis Library, GRNWRE File ("The Court's decision is a stunning defeat for the antienvironmental 'polluter-backed, property rights' coalition.") (quoting David Gardiner, legislative director of the Sierra Club); Statement on the Supreme Court Decision in the Lucas Case, News Release from the National Trust for Historic Preservation (June 29, 1992) ("The Court's ruling . . represents a significant defeat for those who predicted that the Court would announce a major enlargement of property rights .....") (on file with the Stanford Law Review). 
before the 1992 presidential election. Thus, they sought accelerated Supreme Court review of the Pennsylvania case to ensure a ruling during the 1991 Term, and then prepared to condemn the outcome.

Environmentalists, on the other hand, did not welcome the Court's decision to grant review in Lucas because they feared that the likely adverse ruling would chill environmental regulations. They anticipated that a state or local environmental protection agency would reduce its regulatory efforts if it thought that the Supreme Court had dramatically increased the government's obligation to compensate owners of property subject to environmental protection laws. Based on the assumption that few regulators would actually read the opinion, whereas many would react to news reports, environmentalists sought to use the media to control the ruling's immediate impact. ${ }^{6}$ The result was an orchestrated, and largely successful, effort to prompt the national news media to characterize the Lucas decision as legally insignificant. ${ }^{7}$

The case for the Lucas decision's insignificance is easy to make. The Supreme Court based its ruling for the landowner on the factual assumption that the challenged developmental restriction had deprived the landowner of the entire economic value of his property. ${ }^{8}$ But no member of the Court seemed to believe that this assumption was valid. Four Justices explicitly questioned its accuracy, ${ }^{9}$ and the majority opinion carefully avoided any intimation to the contrary. ${ }^{10}$ The majority also declined to identify "the "property interest' against which the loss of value is to be measured," thereby depriving the elimination of economic use test of all but "rhetorical force."11 The Court's comments on the taking issue could therefore justifiably be deemed mere sport, which is why Justice Souter saw "little utility in attempting to deal with this case on the merits" and voted to dismiss the writ

6. Rudy Abrahamson, High Court Backs Compensation for Losses of Land Use, L.A. TIMES, June 30, 1992, at A15 ("But environmentalists, who had feared that a court ruling might sharply inhibit efforts to protect wetlands and combat beach erosion, hailed the decision because it was closely confined to the South Carolina law."); Karen Riley, Land Ruling Called Overly Narrow, WASH. TIMES, June 30, 1992, at A4 ("'I don't think it will have too much of an impact.' ") (quoting David Gardiner of the Sierra Club); Karl Vick, States Could Pay for Land Value Loss, ST. Petersburg Times, June 30, 1992, at Al ("Environmental groups, having feared a broader decision that might have undercut the premise of more regulation, expressed relief.").

7. J. Linn Allen, Court Boosts Property Rights vs. Regulation, CHI. TRIB., June 30, 1992, at C1 ("[T]he decision was not, as some had expected, a broad rebuke to government land-use regulations."); Linda Greenhouse, Justices Ease Way to Challenge Land Use Rules That Prevent Development, N.Y. TIMES, June 30, 1992, at A18 ("But the 6-to-3 decision stopped well short of the sweeping vindication of property rights that many conservatives had hoped for."); Tom Kenworthy \& Kirsten Downey, South Carolina May Have to Pay Compensation in Property Case, Wash. Post, June 30, 1992, at A10 ("[T] he ruling was something of a disappointment to supporters of an expansive interpretation of the Fifth Amendment's 'just compensation' clause.").

8. Lucas, $112 \mathrm{~S}$. Ct. at 2890 (quoting the trial court's finding that the regulation of Lucas' lots "render[ed] them valueless") (alteration in original).

9. Id. at 2903 (Kennedy, J., concurring); id. at 2908 (Blackmun, J., dissenting); id. at $2919 \mathrm{n} .3$ (Stevens, J., dissenting); id. at 2925 (Statement of Souter, J., arguing for dismissal of certiorari).

10. Id. at 2896 n.9.

11. Id. at 2894 n.7. 
as improvidently granted. 12

But the likely practical insignificance of the ruling for the South Carolina Coastal Council is only an incidental aspect of Lucas. The Supreme Court rarely grants review simply to decide a particular case. The Court's opinions are intended to reach a far wider audience. The Justices know that lower courts interpret the Court's opinions as signalling doctrinal shifts, which the lower courts then amplify in their own district and appellate court rulings. Thus, like the environmentalists and the pro-choice advocates, Supreme Court justices frequently add "spin" to their opinions to encourage overreading. Justice Scalia, who wrote the Court's opinion in Lucas, may well be the current master of such opinion-writing "spin."

Like many of Scalia's opinions, ${ }^{13}$ Lucas promises more than it delivers, perhaps with the hope that the lower courts will mistake the promise for the delivery and adopt its broad language rather than its narrow holding. ${ }^{14} \mathrm{But}$ what makes Lucas truly fascinating is that its effect may be far different from that likely envisioned by the majority, or at least by Justice Scalia. Lucas may not in fact portend a doctrinal shift toward enhanced Fifth Amendment scrutiny of environmental restrictions on real property. Ironically, the more likely effect will be fewer successful takings challenges.

The purpose of this essay is to explain why this is so. The essay is divided into three parts. Part I describes and discusses the significance of the Lucas majority's desire to draft an opinion making environmental regulations more susceptible to takings challenges. Part II identifies the majority's antiquated notions of the physical and social function of real property as the source of the majority's misguided efforts. Finally, Part III describes how the majority's analytical framework may ultimately make it easier, rather than harder, for environmental protection measures to survive takings challenges.

\section{Property Versus Environmental Protection}

Understanding Lucas requires historical perspective, albeit of recent vintage. The last twelve years have seen a steady shift in the conservative ideological agenda. Arguments over "states rights," "judicial activism," and "separation of powers" have given way to the "takings issue" as the predominant political litmus test for conservative lawmakers.

The transition is understandable. The formative years for many contemporary conservatives were during the Carter presidency, when they had little influence over federal policy or the selection of federal judges. As a result, they sought to limit the reach of federal agencies and judges by trumpeting

12. Id. at 2925-26 (Statement of Souter, J., arguing for dismissal of certiorari).

13. See, e.g., Nollan v. California Coastal Comm'n, 483 U.S. 825 (1987).

14. Unfortunately, that is precisely what happened on remand in Lucas itself. Without the benefit of a full briefing on either the validity of the trial court's factual finding of no economic value or the applicability of the nuisance exception, the South Carolina Supreme Court perfunctorily ruled that the state law amounted to a temporary taking and remanded for further proceedings on the measure of damages. Lucas v. South Carolina Coastal Council, 424 S.E.2d 484 (S.C. 1992). 
federalism concerns and by decrying judicial activism. But their interest in preserving state autonomy naturally waned during the Reagan and Bush Administrations, as conservative ideological influence on federal policy and judicial selection steadily increased. The "federalism police" within the Justice Department, who had tended to cast a skeptical eye on federal preemption arguments, ${ }^{15}$ were now often in conflict with Reagan Administration policies.

Conservatives turned next to the "separation of powers" doctrine as a means of limiting regulatory encroachments on individual autonomy. Like federalism, separation of powers offered the pretense of a neutral legal principle that in fact favored their ideological goals once conservatives controlled the executive branch. From this perspective, it seems more than mere coincidence that the separation of powers fervor gained particular prominence among conservatives after the Democratic Party regained control of the Senate in 1986, because the democratic victory increased the conflict between the (Republican-controlled) executive and (Democrat-controlled) legislative branches. ${ }^{16}$

The rise of the "takings issue" is the latest and most interesting shift in the conservative agenda. Its ascension reflects both the successes and failures of conservative efforts to influence federal policy. In the eyes of many conservatives, the Reagan and Bush Administrations failed to deliver on their promise of relief from "unnecessary" regulation, especially in the area of environmental protection. The aggressive deregulation efforts of EPA Administrator Anne Gorsuch and Secretary of the Interior James Watt resulted in more embarrassment than fundamental change. ${ }^{17}$ Environmental regulations have actually increased during the past twelve years, largely due to congressional distrust of Administration policies and the tenacity of agency bureaucracies. ${ }^{18}$

The takings issue responds to this political failure by exploiting the conservative movement's greatest success: its capture of the federal judiciary. With the appointment of a critical mass of federal judges receptive to the concerns of business, the Takings Clause offers a way to insulate commercial interests from the regulatory "excesses" that the Reagan and Bush Adminis-

15. See Charles Fried, Order and Law: Arguing the Reagan Revolution-A Firsthand Account 186-88 (1991); see also John O. McGinnis, Principle Versus Politics: The Solicitor General's Office in Constitutional and Bureaucratic Theory, 44 STAN. L. REV. 799, 800 \& nn.7-8 (1992) (book review).

16. See, e.g., Morrison v. Olson, 487 U.S. 654 (1988) (rejecting "separation of powers" challenge to provisions of the Ethics in Government Act relating to the appointment of independent counsels).

17. See generally Jonathan Lash, Katherine Gillman \& David Sheridan, A Season OF SPOILS: THE REAGAN ADMINISTRATION'S ATTACK ON THE ENVIRONMENT (1984) (chronicling the attempts of Reagan appointees to defeat environmental regulation).

18. See generally George Cameron Coggins \& Doris K. Nagel, "Nothing Beside Remains": The Legal Legacy of James G. Watt's Tenure as Secretary of the Interior on Federal Land Law and Policy, 17 B.C. ENVTL. AFF. L. REv. 473 (1990) (arguing that Watt tried and failed to swing back the pendulum of public land law and policy); Richard J. Lazarus, The Tragedy of Distrust in the Implementation of Federal Environmental Law, 54 LAW \& CONTEMP. PROBS. 311 (1991) (concluding that environmental regulation has survived 12 years of conservative administrations). 
trations failed to eliminate. Indeed, the Takings Clause is a particularly powerful approach because as a constitutional brake on reform, it is less susceptible to shifting political winds. Judicial ideology has a longer half-life than its counterparts within the legislative or executive branches; unlike legislative reworking of federal statutes or agency rules, constitutional amendments have proven virtually impossible to achieve.

Both the Court's decision to grant review in Lucas and Justice Scalia's majority opinion reflect the Taking Clause's new-found prominence on the conservative agenda. Since 1978, the Justices' concern about the impact of environmental regulation on private property has regularly led them to review state court rejections of takings challenges to environmental restrictions. Even so, the success record of private property advocates before the Court has been remarkably mixed.

While landowners have often succeeded in obtaining review of lower court failures to find unconstitutional takings, the Supreme Court ultimately has ruled against most of their challenges. ${ }^{19}$ And in every case brought by the government, the Court has reversed the lower court finding of an unconstitutional taking. ${ }^{20}$ In 1987, the Court finally issued three rulings favorable to landowners in Hodel v. Irving, ${ }^{21}$ Nollan v. California Coastal Commission, 22 and First English Evangelical Lutheran Church v. County of Los Angeles. ${ }^{23}$ But the net effect of that Term was mitigated by the Court's rejection of the landowner's takings claim in Keystone Bituminous Coal Ass'n v. DeBenedictis, ${ }^{24}$ the most sweeping of the four decisions. ${ }^{25}$

The 1991 Term, however, promised to be different. Two of the five Justices in the Keystone majority had left the Court. Conservatives were confident that two of the three new Justices, Kennedy and Thomas, ${ }^{26}$ would be squarely in the pro-property camp and hopeful that the third, Justice Souter,

19. The Court disappointed the property owners in MacDonald, Sommer \& Frates v. County of Yolo, 477 U.S. 340 (1986); Connolly v. Pension Benefit Guar. Corp., 475 U.S. 211 (1986); San Diego Gas \& Elec. Co. v. City of San Diego, 450 U.S. 621 (1981); Agins v. City of Tiburon, 447 U.S. 255 (1980); PruneYard Shopping Ctr. v. Robins, 447 U.S. 74 (1980); Andrus v. Allard, 444 U.S. 51 (1979) (But cf. Kaiser Aetna v. United States, 444 U.S. 164 (1979) (a case from the same year upholding a landowner's takings claim)); and Penn Cent. Transp. Co. v. New York City, 438 U.S. 104 (1978).

20. The Court overturned lower court rulings unfavorable to the government in United States v. Riverside Bayview Homes, Inc., 474 U.S. 121 (1985); Williamson County Regional Planning Comm'n v. Hamilton Bank, 473 U.S. 172 (1985); Ruckelshaus v. Monsanto Co., 467 U.S. 986 (1984); Hodel v. Indiana, 452 U.S. 314 (1981); and Hodel v. Virginia Surface Mining \& Reclamation Ass'n, 452 U.S. 264 (1981).

21. 481 U.S. 704 (1987).

22. 483 U.S. 825 (1987).

23. 482 U.S. 304 (1987)

24. 480 U.S. 470 (1987).

25. The Court also rejected a takings challenge to the federal Pole Attachments Act, which authorizes the Federal Communications Commission to determine the "just and reasonable" rate that utilities can charge cable television systems for the use of their utility poles. FCC v. Florida Power Corp., 480 U.S. 245 (1987). The following Term, the Court rejected a takings challenge to a rent control law. Pennell v. City of San Jose, 485 U.S. 1 (1988).

26. During Justice Thomas' confirmation hearings, Senator Biden revealed his concern over the takings issue in his opening statement, which focused on Thomas' activist views on the use of the Takings Clause to protect private property from government regulation. Linda Greenhouse, The 
would share that position. Resurrection of heightened constitutional protection of property interests seemed imminent when the Court quickly granted certiorari in three cases (including Lucas) challenging government regulation of land use on takings and due process grounds. ${ }^{27}$ The Court simultaneously rejected a request by the federal government for review of a lower court opinion that upheld a takings challenge on grounds strikingly reminiscent of Chief Justice Rehnquist's Keystone dissent. ${ }^{28}$

For much of last spring, however, the Court seemed ready to frustrate the private property bar yet again, as two of the three property law cases quickly fell by the wayside. Justice O'Connor's opinion for the Court in Yee v. City of Escondido 29 rejected the property owner's efforts to expand the Court's per se physical invasion takings test to encompass regulation of mobile home parks. The Court also declined to consider the petitioner's alternative contention that, although no actual physical invasion occurred, the county ordinance amounted to a "regulatory taking" because it deprived mobile home park owners of the economic use of their property. The Yee Court's description of the regulatory takings test as ad hoc balancing seemed to indicate its willingness in Lucas to bury the notion, first suggested in Agins v. City of Tiburon, that a deprivation of all "economically viable use" amounted to a per se taking. ${ }^{30}$

The second case, PFZ Properties, Inc. v. Rodriguez, ${ }^{31}$ similarly fizzled. That case involved a substantive due process challenge to state land use regulations. Following oral argument, the Court dismissed the writ of certiorari as improvidently granted, apparently because there was less to the merits of the constitutional claim than first appeared. ${ }^{32}$ The oral argument transcript suggests that some members of the Court believed that the petition for a writ of certiorari's characterization of government misconduct was not supported by the record before the Court, ${ }^{33}$ and that other Justices were not sympathetic to the claim of a "property right" in the receipt of a construction permit from the government. ${ }^{34}$

Thomas Hearings: The Opening Skirmish; Thomas Scores Points in the Crucial Battle for the First Impression, But So Do Critics, N.Y. TIMES, Sept. 11, 1991, at A1.

27. The other two were Yee v. City of Escondido, 112 S. Ct. 1522 (1992) and PFZ Properties, Inc. v. Rodriguez, 112 S. Ct. 1151 (1992).

28. Whitney Benefits, Inc. v. United States, 926 F.2d 1169 (Fed. Cir.), cert. denied, 112 S. Ct. 406 (1991).

29. 112 S. Ct. 1522 (1992).

30. Agins v. City of Tiburon, 447 U.S. 255, 260 (1980). The Court's opinion in Yee avoided any reference to the "economically viable use" test, which the Court had reflexively invoked in virtually all of its takings cases since Agins in 1980. The opinion instead described the regulatory takings analysis in terms of an ad hoc balancing test that "necessarily entails complex factual assessments of the purposes and economic effects of government actions." Yee, 112 S. Ct. at 1526. Instead of citing Agins or its progeny, Justice O'Connor's majority opinion cited Justice Brennan's opinion for the Court in Penn Central Transportation Co. v. New York City, 438 U.S. 104 (1978). Yee, 112 S. Ct. at 1526 .

31. 928 F.2d 28 (1st Cir. 1991), cert. dismissed, 112 S. Ct. 1151 (1992).

32. Id.; Official Transcript Proceedings Before the Supreme Court of the United States, PFZ Properties, Inc. v. Rodriguez, 112 S. Ct. 1151 (1992) (No. 91-122).

33. See Official Transcript Proceedings at 3-7, PFZ Properties (No. 91-122).

34. Id. at 8-16. 
The briefing and much of the oral argument in Lucas suggested the possibility of an equally disappointing result for the landowner. In his petition for a writ of certiorari, the landowner characterized the issue as whether a state law that deprives a property owner of all the economic value of her land in order to confer environmental benefits on the public constitutes an unconstitutional taking. ${ }^{35} \mathrm{But}$, as often happens, a very different case emerged from the briefs and oral argument.

In his brief, the landowner, Lucas, proposed a simple rule: "[T]he enforcement of land-use regulations which have the effect of eliminating the value of private property should be per se subject to the just compensation requirement of the Fifth Amendment." 36 During oral argument, counsel for Lucas acknowledged, after some resistance, that Lucas was asking the Court to adopt such a per se rule, under which a regulation would constitute a taking "[i]f it takes away all the economic value," independent of whether a nuisance or threat to public safety exists. ${ }^{37}$ The Justices' questioning, however, reflected substantial skepticism about the wisdom of such a rule. ${ }^{38}$ And, as this was the only legal argument made by Lucas before the South Carolina Supreme Court, ${ }^{39}$ affirmance seemed surprisingly within South Carolina's grasp.

With the benefit of hindsight, however, the more prophetic moment at oral argument was not the discussion of the per se rule, but Justice White's inadvertent reference to the South Carolina Supreme Court as "the California court." 40 What Justice White's offhand remark crystallized was that certain members of the Court, including one whose vote was necessary for an affirmance, were unlikely to confine themselves to the boundaries presented by the facts and legal arguments in the case before the Court. A disproportionate number of the takings cases to reach the Supreme Court since 1978 originated in California, ${ }^{41}$ whose federal and state court environmental deci-

35. Petition for a Writ of Certiorari to the Supreme Court of the State of South Carolina at $i$, Lucas v. South Carolina Coastal Council, 112 S. Ct. 2886 (1992) (No. 91-453) [hereinafter Lucas Certiorari Petition].

36. Petitioner's Brief on the Merits at 19, Lucas v. South Carolina Coastal Council, $112 \mathrm{~S}$. Ct. 2886 (1992) (No. 91-453); see also id. at 28-35.

37. Official Transcript Proceedings Before the Supreme Court of the United States at 25, Lucas v. South Carolina Coastal Council, 112 S. Ct. 2886 (1992) (No. 91-453) [hereinafter Lucas Oral Argument Transcript].

38. Id. at 16 ("[I]t seems to me that there are instances in which all economic viability can be deprived because of an urgent safety reason, and that there's no taking."); id. at 17 ("But that wasn't challenged in this case. All of you-your whole theory is that if all economic viability is lost, that that's the end of the case."); id. at 25 ("You want the per se rule, and you argued it below. If it takes away all the economic value, it is a taking that has to be compensated. They are saying that is so sometimes but not all the time, that if there is a nuisance, if it is threatening the public safety, you can take it all away without paying and you deny that.").

39. See Respondent's Brief on the Merits at 1-6, Lucas v. South Carolina Coastal Council, 112 S. Ct. 2886 (1992) (No. 91-453).

40. Lucas Oral Argument Transcript, supra note 37, at 39.

41. Yee v. City of Escondido, 112 S. Ct. 1522 (1992); Pennell v. City of San Jose, 485 U.S. 1 (1988); Nollan v. California Coastal Comm'n, 483 U.S. 825 (1987); First English Evangelical Church v. County of Los Angeles, 482 U.S. 304 (1987); MacDonald, Sommer \& Frates v. County of Yolo, 477 U.S. 340 (1986); San Diego Gas \& Elec. Co. v. City of San Diego, 450 U.S. 621 (1981); 
sions seem to attract great skepticism from the Supreme Court. Supporters of the state law in Lucas had hoped that its heralding from the more conservative shores of South Carolina would reduce the possibility of the Court's associating the South Carolina law with California judicial excesses. Justice White's twice-repeated reference to the California courts suggested otherwise. ${ }^{42}$ The Justices were more likely to view the South Carolina law as part of a broader national problem requiring the Court's attention.

The Court's opinion reflected this broad view of the issues at stake. The majority surmounted a range of obstacles to reach the merits of the case, including ripeness, standing, and the sheer improbability of the lower court's factual findings. In ruling on the merits, the Court ultimately purported to endorse the landowner's position when, in fact, it squarely rejected his core legal theory.

Both at trial and before the South Carolina Supreme Court, the landowner had exclusively pursued the narrow legal theory that the South Carolina law's economic impact on the land's market value rendered the law's operation a per se taking. According to Lucas, the character or degree of physical harm that the restriction sought to avoid was irrelevant to the law's constitutionality. Hence, Lucas brought the lawsuit without ever challenging the Coastal Council's conclusion that placement of the setback line (delineating the closest point to the shore suitable for permanent structures) landward of his property was warranted. ${ }^{43}$ Pursuant to this strategy, Lucas' counsel objected at trial to the introduction of any evidence of the "erosion [that could result from the] construction of habitable structures along the beach front," 44 contending that such evidence was irrelevant to the issue before the court. ${ }^{45}$ Lucas had presented a similarly narrow argument before the state supreme court. 46

The Lucas majority, however, did not embrace the landowner's view that economic impact alone could transform a land use restriction on development into an unconstitutional taking. The majority concluded instead that there were circumstances where no compensation would be required even though a regulation deprived the landowner of all economic value. ${ }^{47}$ The majority at first described these circumstances fairly narrowly, as requiring a

Agins v. City of Tiburon, 447 U.S. 255 (1980); PruneYard Shopping Ctr. v. Robins, 447 U.S. 74 (1980).

42. The Supreme Court's official transcript records Justice White's mistake only once. Lucas Oral Argument Transcript, supra note 37, at 39. I attended the oral argument on behalf of the South Carolina Coastal Council and recall an earlier reference, which is not in the transcript.

43. Lucas, 112 S. Ct. at 2907 (Blackmun, J., dissenting).

44. Transcript of Record at 94-95, Lucas v. South Carolina Coastal Council, No. 89-CP-100066 (Ct. of Common Pleas Aug. 7, 1989), rev'd, 304 S.C. 376, 404 S.E.2d 895 (1991), and rev'd, 112 S. Ct. 2886 (1992) [hereinafter Lucas Trial Transcript] (on file with the Stanford Law Review); see 112 S. Ct. at 2906 (Blackmun, J., dissenting).

45. Lucas Trial Transcript, supra note 44, at 94-95.

46. Lucas v. South Carolina Coastal Council, 404 S.E.2d 895, 896 (S.C. 1991), rev'd, 112 S. Ct. 2886 (1992).

47. Some of the majority's formulations of the threshold inquiry include whether the challenged law "denies all economically beneficial or productive use of land," Lucas, $112 \mathrm{~S}$. Ct. at 2893, deprives the owner of " 'all economically feasible use," "id. at 2894 n.7, "eliminate[s] all economi- 
showing "that the proscribed use interests were not part of his title to begin with." 48 But the scope of this exception expanded significantly when the Court characterized regulations that "inhere in the title itself" as including "restrictions that background principles of the State's law of property and nuisance already place upon land ownership."49 This proposed "nuisance" exception was precisely what Lucas had argued against throughout the litigation.

The Court elaborated on the "background principles" exception in terms entirely consistent with the "harm" inquiry proposed by the South Carolina Coastal Council. In fact, the Court's nuisance analysis-one of the "background principles of law" that "inhere in the title"-embraced the very same balancing test that it had discarded in previous paragraphs. According to the Court, the " 'total takings' inquiry" will

ordinarily entail ... analysis of, among other things, the degree of harm to public lands and resources, or adjacent private property posed by the claimant's proposed activities[,] . . . the social value of the claimant's activities and their suitability to the locality in question, and the relative ease with which the alleged harm can be avoided through measures taken by the claimant and the government (or adjacent private landowners) alike.50

The Court also pointed out that application of these background principles is a dynamic rather than static exercise. While the underlying legal principles may remain the same over time, the restrictions on the use of property could legitimately change. As the Court freely acknowledged, "changed circumstances or new knowledge may make what was previously permissible no longer so." 51 The Court suggested two circumstances where new information could lead to complete prohibitions on development that would survive a takings challenge: landfilling that would cause the flooding of neighboring properties and nuclear power plant construction on a newly discovered earthquake fault. ${ }^{52}$ As described in South Carolina Coastal Council's brief before the Court, however, the harms its challenged restrictions sought to prevent are analogous to the harms in the Court's two examples. ${ }^{53}$

What is therefore perhaps most striking about the majority ruling in $\mathrm{Lu}$ cas is the extent to which the Court bent over backwards to draft an opinion that seemed wholly favorable to the landowner, while in fact rejecting much, if not all, of his legal theory. The Court's eagerness to confer a "win" on the landowner in Lucas parallels its apparent desire earlier in the same Term to

cally valuable use," $i d$. at 2900 , or leaves the land "without economic value," $i d$. at 2894 n.7, "without economically beneficial or productive options," id. at 2894, or "economically idle," $i d$. at 2895.

48. Id. at 2899.

49. Id. at 2900 .

50. Id. at 2901 (citing RESTATEMENT (SECOND) OF TORTS $\$ \S 826-827,827$ (e), 828(a)-(c), 830831 (1978)).

51. Id. (citing Restatement (SECOND) OF TORTS $\S 827 \mathrm{cmt}$. g (1978)).

52. Id. at 2900-01.

53. Respondent's Brief at 37-40, Lucas (No. 91-453). 
avoid giving the government a win in $P F Z$ Properties. ${ }^{54}$

The Court's pro-property predilection is revealed most starkly by comparing its actual opinion in Lucas with the one that it could have written on essentially the same grounds in favor of the South Carolina Coastal Council. As discussed above, the only issue before the South Carolina Supreme Court was whether an environmental regulation's economic impact on a particular landowner is enough to render the regulation an unconstitutional taking. 55 The landowner did not deny that his proposed construction might cause a common law nuisance; such inquiry was simply deemed irrelevant to the challenge he advanced. After concluding that a "background principle" or "nuisance" exception to constitutional takings exists, the Lucas majority could have affirmed the state court judgment on precisely such grounds.

Strictly speaking, the South Carolina Supreme Court had answered correctly the only issue before it, when it held that economic impact alone is not enough to establish an unconstitutional taking. To dispose of the case, the United States Supreme Court did not have to consider the state court's characterization of when government action might constitute a compensable deprivation of property, because Lucas did not raise that subsidiary issue in the lower court litigation. Accordingly, the state supreme court simply had no occasion to consider whether the landowner's proposed construction (which, in fact, had never been proposed) would amount to a common law nuisance based on the "background principles" of law against which ownership is defined.

While it is not uncommon for the United States Supreme Court to uphold a lower court judgment on grounds other than those raised in the lower court, the converse (reversing a judgment on independent grounds) is a more questionable practice. It allows a disappointed litigant a second bite at the appellate apple: Lucas was permitted to relitigate his case in state court based on a more palatable legal theory than the one originally offered.

Of course, no jurisdictional bar precludes the Court from reaching out when it disagrees with what it sees as the ultimate import of a lower court's jurisprudence. The Supreme Court is free to dispose of any prudential considerations that would otherwise have prevented the landowner in Lucas from receiving a rehearing. But the Court's generosity towards the landowner contrasts sharply with its refusal to consider the state government's challenge to the trial court's findings of fact. ${ }^{56}$ No jurisdictional bar prevented the Court from examining the critical threshold matter of whether the challenged regulation actually deprived Lucas' land of all economic value. With respect to this argument, however, the Court suddenly found the prudential concerns preclusive. ${ }^{57}$

The Lucas majority was clearly determined, and impatient, to issue a

54. See text accompanying notes 31-34 supra.

55. See text accompanying notes 43-46 supra.

56. 112 S. Ct. at 2896 n.9.

57. Id. 
ruling favorable to the landowner. Less clear is the justification for this impatience. Presumably, the majority thought that environmental restrictions pose a sufficiently serious and immediate threat to private property rights to justify reaching out to provide guidance on an issue arguably more hypothetical than real.

But missing after Lucas is what was missing before: meaningful evidence that the "parade of horribles" envisioned by the Court is in fact occurring to landowners across the country. At least whenever a so-called "horrible" takings case has reached the Supreme Court, a full airing of the facts has revealed only adversarial smoke. ${ }^{58}$ The extreme cases have yet to materialize, which is why the Court in Lucas had to base its ruling on a hypothetical fact pattern. A political movement derived from anecdotal accounts of governmental abuses, rather than an actual case or controversy, is the root of the majority ruling in Lucas.

\section{II. (UN)Real Property}

The majority's current zeal to repel the perceived environmentalist assault on private property rests on serious misperceptions regarding the nature of land. The Court does not appreciate the now-settled ecological notion that land "is not merely soil; it is a fountain of energy flowing through a circuit of soils, plants, and animals." 59 Land is not a discrete, severable resource that respects the surveyor's binary-based boundaries. It is part of a complex, interdependent ecological system. Nor does the Court appreciate that over the past century our relationship to the land has fundamentally changed. Land is now a highly regulated commodity, and its ownership is no longer the touchstone of human autonomy or the source of individual freedom.

The Lucas Court revealed its misperception of the physical realities of land in its remand instructions to the lower court. The Court made quite clear its view that the South Carolina courts should not hold that "background principles of the State's law of property and nuisance" would have barred Lucas from developing his property regardless of the regulation. ${ }^{60}$ The Court stated that there is "ordinarily . . . a lack of any common-law prohibition" when "a particular use has long been engaged in by similarly situated owners," and "other landowners, similarly situated, are permitted to continue the use denied to the claimant." 61 On the off chance that the state courts might miss the Court's not-so-subtle message regarding what "state law" should be, the Court also emphasized that state courts are confined to "an objectively reasonable application of relevant precedents." 62

The Court displayed no appreciation of the factors that led South Caro-

58. See text accompanying notes 19-25 supra. (1949).

59. Aldo Leopold, A Sand County Almanac and Sketches Here and There 216

60. Lucas, 112 S. Ct. at $2900,2901-02$.

61. Id. at 2901 .

62. Id. at 2902 n.18. Certainly the South Carolina Supreme Court got the message, as it 
lina to conclude that the physical characteristics of Lucas' land made it the wrong place for the construction of a house. The Court ignored the applicability of its own parenthetical acknowledgment that "changed circumstances or new knowledge may make what was previously permissible no longer so,"63 without offending the Takings Clause. South Carolina had enacted this law precisely because of its enhanced understanding of the dangers posed by future development, and of how preexisting development increased, rather than diminished, those dangers.

The land at issue in Lucas is virtually a mirage. The property is immediately adjacent to the shore, with no natural barrier to separate the proposed construction sites from the ocean. Subject to the daily action of the tide and erosion from storms, the shifting sands of Lucas' beach are no more static than the waters that constantly transform them. Both of Lucas' lots were entirely under water as recently as 1963 , and partially covered by ocean ponds as late as $1973 .{ }^{64}$ Further, due to the competing forces of accretion and erosion, the shoreline has been landward of Lucas' seaward property line 50 percent of the time since 1949, and landward of the road behind Lucas' lots 15 to 20 percent of the time over that same period. ${ }^{65}$

One can easily see how and why the construction of a permanent structure on Lucas' property might be dangerous to its inhabitants or neighboring properties. Normally, the construction of a single-family home does not present dangers to human health and safety. But the fragile, ever-shifting ground near the shoreline is not like most places. A house on such unstable land presents acute risks. That a house ordinarily serves a benign residential purpose does not immunize it from the natural forces of the coastal zone. ${ }^{66}$

The extent to which the individual Justices' abilities to appreciate the physical characteristics of land influenced the outcome in Lucas is best demonstrated by contrasting the majority opinion with the concurring opinion filed by Justice Kennedy. Court watchers who had anticipated Justice Kennedy's solid vote in favor of the landowner in Lucas were no doubt surprised by his opinion. Although Kennedy agreed that a remand was warranted, he remained open to the possible legitimacy of the South Carolina Coastal Council's position. He contended that the "State should not be prevented from enacting new regulatory initiatives in response to changing con-

quickly concluded that there had been a taking, even though it lacked a full briefing on the applicability of South Carolina nuisance law to the case. See note 14 supra.

63. Lucas, 112 S. Ct. at 2901 (citing RESTATEMENT (SECOND) OF TORTS $\S 827 \mathrm{cmt} . \mathrm{g}$ (1978)); see also text accompanying notes $51-53$ supra.

64. Lucas, 112 S. Ct. at 2905 (Blackmun, J., dissenting).

65. Lucas Trial Transcript, supra note 44, at 113.

66. Nor should the fact that many others had constructed homes in the past prevent South Carolina from barring similar construction in the future. In the words of the Lucas majority, any seeming unfairness is simply the price of "mak[ing] what was previously permissible no longer so" based on "changed circumstances or new knowledge." $112 \mathrm{~S}$. Ct. at 2901 (citing ResTatemeNT (SECOND) OF TORTS $\$ 827 \mathrm{cmt} . \mathrm{g}(1978)$ ). Certainly South Carolina's failure to apply the restriction retroactively and order the removal of existing structures does not undermine its purpose. Such a measure would raise a qualitatively different, and more serious, Takings Clause problem. It would require a "physical invasion" of the land and would destroy part of the realty itself (such as a house). 
ditions." 67 Nuisance law, he added, should not be "the sole source of state authority to impose severe restrictions." 68 Explicitly recognizing the significance of a resource's physical characteristics, Kennedy commented that "[c]oastal property may present such unique concerns for a fragile land system that the State can go further in regulating its development and use than the common law of nuisance might otherwise permit."69

As a Californian, Justice Kennedy's insight into the desirability of environmental regulation may stem from personal experience. California courts have historically been particularly responsive to environmental concerns, possibly because Californians have more reason to be aware of the hidden perils in land which, to the untrained eye, might seem appropriate for unrestricted development. In California, the repeated losses of life and destruction of property caused by earthquakes, mudslides, floods, and fires serve as effective teachers. ${ }^{70}$ Analogous lessons based on historical experience prompted South Carolina, a state hardly known for regulatory excess, to enact the restrictions challenged in Lucas. ${ }^{71}$ South Carolina, unlike the Lucas majority, understood the very real dangers of adhering to cultural fictions regarding land when the land in question is part of a fragile and interdependent ecosystem.

The Court's decision to provide heightened constitutional protection to developmental uses of real property was as disturbing as its ignorance of the potential fragility of land. The Lucas Court drew a curious, yet sharp distinction between personal and real property. The Court concluded, in effect, that an owner of personal property is entitled to relatively less protection under the Takings Clause: "[B]y reason of the State's traditionally high degree of control over commercial dealings, [the owner of personal property] ought to be aware of the possibility that new regulation might even render his property economically worthless." 72 The Court found, however, no comparably diminished expectations in real property rights. Such a notion, the Court explained, would be "inconsistent with the historical compact recorded in the Takings Clause that has become part of our constitutional culture."73

The Court's distinction between the expectations of real and personal property holders does not derive from the text of the Takings Clause, ${ }^{74}$ which appears to apply to "real" and "personal" property alike. And, of

67. Id. at 2903 (Kennedy, J., concurring).

68. Id. (Kennedy, J., concurring).

69. Id. (Kennedy, J., concurring).

70. See, e.g., John McPheE, The ConTrol of NATURe 183-272 (1989) (surveying Los Angeles' battles with nature); Robert Reinhold, In California, Nature Refuses to Remain Mastered, N.Y. TIMES, Oct. 28, 1991, at A1 (commenting on the Oakland firestorm).

71. See generally Report of the South Carolina Blue Ribbon Committee on BeachFRONT MANAGEMENT (1987) (reviewing the environmental situation and recommending that South Carolina institute new regulations).

72. 112 S. Ct. at 2899.

73. Id. at 2900.

74. U.S. CONST. amend. V ("[N]or shall private property be taken for public use, without just compensation."). 
course, the Court's empirical assumption regarding the relative degree of state regulation over the two types of property is questionable. Although there was a time when such a distinction could have validly been made, for the past twenty-five years (long before most current property owners received their titles), regulation of state and local land use has rivaled that of personal property. ${ }^{75}$

The Court's references in Lucas to "historical compact" and "constitutional culture" may reflect an oddly nostalgic view of a very different era. The United States today is not, however, a Jeffersonian society of individual small family farms, where citizens derive their independence and identity from owning discrete plots of land. Today many interests in land are commercial in character, similar to those in personal property. The relationship of land ownership to biological needs and human autonomy is marginal. Even among those persons fortunate enough to own a home on a plot of land, few rely on their land as a primary source of food. For the large number of persons who live and work in major metropolitan areas, land ownership is irrelevant to self-identity.

The facts in Lucas illustrate the increasingly commercial nature of real property. They also challenge the Court's suggestion that the South Carolina law prohibited the " "essential use" " of Lucas' land. ${ }^{76}$ At issue were two relatively small lots ( 90 feet wide by 160 feet deep). The landowner paid $\$ 1$ million for both lots, intending to build a house for himself on the first and to hold the second as an investment. ${ }^{77}$ Lucas' investment interest in the second lot is hard to distinguish from an "extinguishable" commercial interest in personal property. In fact, this investment is similar to ownership of high risk stock. The market value of the lot had apparently increased by almost 100 percent in the year preceding his purchase, and by almost 40 percent the year before that. ${ }^{78}$

Nor can one easily equate the beachfront luxury home Lucas presumably envisioned for the first lot with the "essential uses" of the nineteenth century homesteaders, on which the Court seemed to base its "historical compact" and "constitutional culture" references favoring protection of real property. Lucas' interest in constructing a million-dollar residence on the coast is a distant cousin to the interests of those nineteenth century pioneers who depended on ownership of land for survival. No doubt the pioneers of yesteryear would have viewed the construction of a house on a site so exposed to the elements as dim-witted rather than "essential."

75. State and municipal zoning laws have become increasingly restrictive, as have federal, state, and municipal environmental protection requirements. See generally FRED Bosselman \& David Callies, The Quiet Revolution in Land Use ConTrol (1971) (surveying innovative land use regulations in many states); John Edward Cribbet, Concepts in Transition: The Search for a New Definition of Property, 1986 U. ILL. L. REV. 1 (exploring the changing nature of property rights over the last century).

76. Lucas, 112 S. Ct. at 2901 (quoting Curtin v. Benson, 222 U.S. 78, 86 (1911)).

77. Lucas Certiorari Petition, supra note 35, at app. $\mathrm{C}$ at 33 (reproducing the trial court opinion).

78. Lucas, 112 S. Ct. at 2905 n.3 (Blackmun, J., dissenting). 
Indeed, the Court's readiness to treat Lucas' luxury and investment uses of land as the kind of "essential use" entitled to heightened constitutional protection is the most troubling aspect of Lucas. More appropriate successors to the constitutional protection afforded nineteenth century homesteaders would seem to be individuals seeking judicial protection from arbitrary governmental action-action threatening their ability to enter and become citizens of the United States, to gain employment, or to obtain housing, education for their children, health care, and welfare assistance. These interests, not those of Lucas in the Isle of Palms, are the kind that currently determine the ability of many to survive and that dictate their quality of life.

Unfortunately, recent decades have witnessed the development of a Court increasingly hesitant to use the Constitution to redress these pressing social ills. Phrased in terms of the anti-democratic dangers of an activist federal judiciary, the arguments against judicially framing these interests as constitutional entitlements have some abstract force. Nonetheless, a most unflattering portrait of the Court emerges when its restraint on issues affecting the very survival of many is juxtaposed against its eagerness to protect the highly speculative commercial real property interests at issue in Lucas.

\section{The IRONY OF LUCAS}

It is commonplace to observe that Supreme Court Justices evolve over time in ways that undoubtedly annoy the Presidents who appointed them. Supreme Court rulings are no different, in that their ultimate legal impact often bears little resemblance to the initial expectations of their authors. $\mathrm{Lu}$ cas may be such a case.

Lucas likely reflects the high-water mark for constitutional protection of private property. The case presented awful facts from the government's perspective. Additionally, the Court was dominated by a conservative supermajority that was predisposed against the government's position. Nonetheless, the Court avoided making the extreme pro-property, antiregulation ruling that many had feared.

Indeed, it is hard to imagine worse facts for the defense of a governmental regulation in a takings case. The plaintiff was an individual who wanted to build a house on his land. His neighbors had houses on their property, and the governing law at the time he purchased his lot did not bar such construction. After a trial, the state lower court found that the development restriction barring the plaintiff from building a house had rendered his property valueless. ${ }^{79}$

Notwithstanding this factual backdrop and a Court dominated by conservative Justices selected by Presidents (Reagan and Bush) sympathetic to landowner claims of government excesses, the Lucas Court could not muster a majority ruling that a taking had occurred. The Court instead remanded the case, acknowledging that what initially appeared to be a worst case sce-

79. Id. at 2889 . 
nario for the government might not actually amount to an unconstitutional taking. In reaching this conclusion, the Court quietly retreated from its prior categorical statements that the deprivation of all "economically viable use" was by itself enough to render a regulation an unconstitutional taking. ${ }^{80}$

The Court engaged in a shell game by pointedly rejecting a "noxious" or "harmful use" exception to the Takings Clause, only to adopt its analytical equivalent dubbed "background principles of nuisance and property law."81 The stability of those principles is illusory, however, given the Court's explicit recognition that their application requires a balancing of harms and social values and may evolve over time with "new knowledge" or "changed circumstances." 82 That the unsympathetic Lucas majority felt compelled to acknowledge the logic of allowing the law to change in this manner is a hopeful harbinger of what the Court might do in a case with facts more sympathetic to the government.

Furthermore, the majority's intimations that the background principles must be supplied by judge-made common law, rather than by legislative or regulatory enactment, will probably not survive review in the future. Three of the four Justices (Justices Kennedy, Blackmun, and Stevens) who declined to join the majority opinion explicitly criticized this aspect of the holding. ${ }^{83}$ Justice White, who joined the majority opinion, has since announced his resignation, and his successor is unlikely to share much of Justice Scalia's agenda. Finally, Justice O'Connor, who also joined the majority, is unlikely to adhere to that view when pressed in the future.

Commentators too frequently conclude that Justices who join an opinion for the Court necessarily endorse all of its nuances. Especially where, as in Lucas, the Court is handing down a decision issued at the end of the Term, a Justice is unlikely to deprive the Court of a majority over a disagreement with some peripheral suggestions in the opinion. The Justices are rarely that obsessive, partly because the internal institutional cost of rooting out all such problems is frequently too high. ${ }^{84}$ In fact, Justice O'Connor's opinion for the Court in $Y e e^{85}$ undermines the assumption that she embraces all the implications of Justice Scalia's opinion for the Court in Lucas. ${ }^{86}$ In Yee, Justice O'Connor carefully distinguished physical invasion takings from regulatory takings, stating that the latter are not subject to a "clear rule." 87 She also described the deprivation of the "economic use of the property" as just

80. Id. at 2893-94.

81. Id. at 2901.

82. Id.

83. Id. at 2903 (Kennedy, J., concurring); id. at 2916 (Blackmun, J., dissenting); id. at 2921-22 (Stevens, J., dissenting). Justice Souter's separate statement did not address the issue. See id. at 2925-26 (Statement of Souter, J., arguing for dismissal of certiorari).

84. No doubt this is why Justice Scalia joined Justice O'Connor's opinion for the Court in Yee, earlier that same Term, although it contained language seemingly inconsistent with the opinion he was then drafting in Lucas.

85. 112 S. Ct. 1522 (1992).

86. See note 30 supra; text accompanying note 88 infra.

87. 112 S. Ct. at 1526. 
one factor in the "complex factual assessments of the purposes and economic effects of government actions" required to evaluate regulatory takings claims. ${ }^{88}$

Justice O'Connor has also not consistently sided with the pro-property faction on the Court. She joined Justice Stevens' dissent in First English, ${ }^{89}$ suggesting her heightened sensitivity to massive damage awards against state and local governments in takings cases. ${ }^{90}$ O'Connor's opinions also express a general wariness of the competency and propriety of judges second guessing legislative factfinding and policymaking through the guise of constitutional adjudication. ${ }^{91}$ Justice O'Connor would therefore seem unlikely to join Justice Scalia in a case directly addressing the competence of a legislature or a regulatory agency to make the kind of nuisance-like determinations that were the exclusive province of the common law courts in far simpler times. 92

Still, the most important ramification of the Court's efforts in Lucas lies in its increasing emphasis on per se rules to dispose of takings claims. With Lucas, the Court has fashioned two categories of presumptive regulatory takings: physical invasions and deprivation of all economic value. ${ }^{93}$ If the challenged governmental regulation fits into either of the two categories, the takings equivalent of "strict scrutiny" will apply. As a result, a physical invasion will invariably be held a taking, as will a regulation resulting in total economic deprivation, subject to the "background principles" exception.

But, because environmental protection laws almost never result in total economic deprivations, ${ }^{94}$ that categorical presumption will rarely apply. Instead, the negative implication of the category's nonapplicability will dominate the lower courts' takings analyses. These courts will likely apply the opposite presumption that no taking has occurred.

88. Id.

89. 482 U.S. 304, 322 (1987) (Stevens, J., dissenting).

90. Justice White would likewise not have been a dependable vote in favor of Justice Scalia's views in future cases, had Justice White decided to remain on the Court. Justice White joined the majority opinion in Keystone, 480 U.S. 470 (1987), which shares little with Justice Scalia's reading of the Takings Clause in Lucas.

91. Richard A. Cordray \& James T. Vradelis, The Emerging Jurisprudence of Justice O'Connor, 52 U. CHI. L. REv. 389, 417-22 (1985); see also id. at 417 (observing that Justice O'Connor "seeks to have the Court wherever feasible, exercise its power to review legislation in a way that minimizes the constitutional impediments to legislative actions").

92. See Jeff L. Lewin, Boomer and the American Law of Nuisance: Past, Present, and Future, 54 ALB. L. REV. 189, 229-30 (1990) (commenting on the inadequacy of nuisance law to address modern air and water pollution).

93. $112 \mathrm{~S}$. Ct. at 2893 (positing that "at least two discrete categories of regulatory action [are] compensable without case-specific inquiry into the public interest advanced in support of the restraint").

94. Environmental laws often bar the most profitable use, but they only rarely eliminate all economic uses of property, as the Lucas majority acknowledged both directly, see id. at 2894 (asserting that these situations are "relatively rare"), and indirectly, by distinguishing prior precedent, see id. at 2899 ("None [of our prior cases] that employed the logic of 'harmful use' prevention to sustain a regulation involved an allegation that the regulation wholly eliminated the value of the claimant's land."). 
Such a presumption would parallel judicial tendencies in several other areas of constitutional analysis. Within the First Amendment, Commerce Clause, Equal Protection, and Due Process doctrines, the courts apply a two-tiered approach. If "strict scrutiny" applies, the government must show that the challenged law is narrowly tailored to serve a compelling state interest. Otherwise, the law need only meet the less exacting "rational basis" standard, which requires that the law be reasonably related to a legitimate governmental purpose. In practice, the two-tier framework means that the courts' threshold determinations of which standard of review to apply decides the constitutional question: Under strict scrutiny, the law is inevitably struck down; under rational review, it stands.

The judicial tendency to rely on reverse presumptions seems to have occurred in the Supreme Court's application of the administrative law doctrine announced in Chevron U.S.A., Inc. v. Natural Resources Defense Council, Inc. ${ }^{95}$ The Chevron Court instructed the lower courts to defer to an administrative agency's reasonable interpretation of the statutory language it administrates, unless the meaning of that language is unambiguous. ${ }^{96}$ Although hailed (and criticized) for promoting judicial deference to administrative agency interpretations, the Chevron two-step analysis may actually have had the opposite effect. The courts regularly conclude that Congress has, in fact, addressed the issue directly in the statutory language, and hence give no deference to the agency construction of the law. The result has been less, rather than more, deference to agency interpretations. ${ }^{97}$

The same phenomenon may occur in Lucas' aftermath. When claims of regulatory takings arise, lower court litigation will initially focus on whether there has been a complete deprivation of economic value. Once the government has disproved total economic loss, a task which should not be difficult, the court will be deprived of the advantages of a per se rule. Faced with the unprincipled vagaries of the multifaceted balancing test prescribed by Penn Central, 98 the court will most likely apply rational basis scrutiny and simply sustain the governmental action. This result is particularly likely now that the Lucas Court has indicated that there is no principled basis for distinguishing between promoting public benefits and preventing public harm. ${ }^{99}$

95. 467 U.S. 837 (1984).

96. Id. at $842-45$.

97. See Thomas W. Merrill, Judicial Deference to Executive Precedent, 101 YALE L.J. 969, 980-93 (1992).

98. 438 U.S. 104 (1978)

99. $112 \mathrm{~S}$. Ct. at 2897-99. There have been few federal and state court takings decisions in the short time since Lucas. The early returns, however, suggest the potential force of Lucas' negative presumption. See, e.g., Naegele Outdoor Advertising, Inc. v. City of Durham, 803 F. Supp. 1068 (M.D.N.C. 1992) (rejecting takings challenge to prohibition on commercial, off-premise advertising signs); Tabb Lakes, Inc. v. United States, $26 \mathrm{Cl}$. Ct. 1334 (1992) (rejecting takings challenge to temporary assertion of federal wetlands jurisdiction); State v. Booker, No. 90C-N0-31, 1992 Del. Super. LEXIS 366 (Del. Super. Ct. Sept. 9, 1992) (rejecting takings challenge to prohibition on building after finding Lucas inapplicable); Bernardsville Quarry, Inc. v. Borough of Bernardsville, 129 N.J. 221, 608 A.2d 1377 (1992) (rejecting takings challenge to limitation on depth of mining that reduced value of land by over 90\%); Powers v. Skagit County, 835 P.2d 230, 237 (Wash. Ct. App. 1992) ("[U]nless [the plaintiff] can demonstrate on remand that he is entitled to categorical treat- 
The final reason for hope after Lucas lies in the majority's efforts to harmonize takings analysis with other constitutional doctrines. Most promising is the Lucas Court's suggestion, analogizing from Free Exercise Clause precedent, that "generally applicable" environmental restrictions are not unconstitutional takings when, unlike the South Carolina law, they are not "aimed at land" in the first instance. ${ }^{100}$ In Employment Division, Department of Human Resources $v$. Smith, ${ }^{101}$ the Court, in an opinion authored by Justice Scalia, held that a generally applicable criminal prohibition on the use of a drug did not violate the Free Exercise Clause when applied to someone using that drug for religious purposes. ${ }^{102}$ While disagreeing with Justice Stevens' claim that the South Carolina law was such a generally applicable law, the Lucas majority acknowledged the validity of the analogy in other takings cases. "Perhaps," the majority stated, "a law that destroys the value of land without being aimed at land . . . cannot constitute a compensable taking." 103 Because most environmental restrictions, such as the Clean Air Act ${ }^{104}$ or Clean Water Act, ${ }^{105}$ are not "aimed at land" in the first instance, such a rule could effectively immunize many environmental protection measures from Takings Clause scrutiny.

Those resisting takings claims might also analogize from free speech precedent in defense of government regulation. Many landowners in takings cases argue that the Fifth Amendment places objective, external limitations on the extent to which environmental laws can reduce expectations in real property rights. Under their analyses, the Constitution imposes a normative view of what private property must be. It follows that state law cannot define away private property rights, even prospectively with notice. To defeat this argument, government lawyers might merge the Lucas Court's acknowledgement that state law defines the contours of property expectations with the Court's deference to "contemporary community standards" in First Amendment obscenity cases. ${ }^{106}$ The latter doctrine is a good example of the Court's refusal to adopt the very kind of uniform federal constitutional standard that private property stalwarts claim should be erected based on the Takings Clause. ${ }^{107}$

As described in Justice Kennedy's concurring opinion in Lucas, a Fourth

ment under Lucas (by showing that his property retains no economically viable use as a result of the regulations), then the trial court's determination that the regulations are insulated from his takings challenge must be affirmed.").

100. 112 S. Ct. at 2899 n. 14.

101. 494 U.S. 872 (1990).

102. Id. at $879-80$ ("[T]he right of free exercise does not relieve an individual of the obligation to comply with a "valid and neutral law of general applicability." ") (citation omitted).

103. Lucas, 112 S. Ct. at 2899 n.14.

104. 42 U.S.C. $\S \S 7401-7671$ (1988 \& Supp. II 1990).

105. 33 U.S.C. $\S \S 1251-1387$ (1988 \& Supp. II 1990).

106. See Miller v. California, 413 U.S. 15, 24 (1973).

107. See, e.g., Stevens v. City of Cannon Beach, 835 P.2d 940, 942 (Or. Ct. App.), review granted, 844 P.2d 206 (Or. 1992) (relying on Lucas to reject a takings claim based on a state court ruling " 'that the purportedly taken property interest was not part of plaintiffs' estate to begin with." ") (quoting Lucas, 112 S. Ct. at 2899). 
Amendment analogy could be similarly helpful to government regulators. ${ }^{103}$ The Court has, in Fourth Amendment cases, ruled that the physical characteristics of property may profoundly affect the reasonableness of a landowner's expectations of privacy. Hence, the Court has held that privacy expectations in a property owner's "open fields" are low enough to allow a warrantless search and seizure, particularly when "these lands . . . are accessible to the public."109

Applying this Fourth Amendment doctrine to Fifth Amendment takings analysis, a court could conclude that the physical characteristics of the resource diminish the property owner's expectations of economic return. This analysis might even apply to government-sponsored physical invasions. In Nollan v. California Coastal Commission, ${ }^{110}$ for example, the Court held that a state law that conditioned a building permit for a beachfront home on the applicant's granting a public easement directly in front of the house amounted to an unconstitutional taking. In Nollan, the property in question would have been outside the "close" for Fourth Amendment purposes, because the beach area in dispute was separated from the house by an eight foot seawall; thus, the Court could have relied on Fourth Amendment precedent to find that the landowner had diminished privacy expectations for Fifth Amendment takings purposes. Nollan would have been a particularly good vehicle for the importation of search and seizure doctrine because the Court's taking determination was rooted in the uniquely serious character of an injury caused by physical invasion of private property.

Lucas' bite may ultimately turn on the lower courts' willingness to accept the majority's invitation to scrutinize state court property and tort rulings to determine whether they are supported by "an objectively reasonable application of relevant precedents." 111 Unfortunately, "takings" plaintiffs may not be able to take advantage of that limitation. State court judges are not likely to conclude that their own application of precedent is not "objectively reasonable." And, while federal judges might be more willing to second-guess their state judicial counterparts, they are not likely to have much opportunity to do so. The Supreme Court's ripeness rules effectively require that "as applied" takings challenges be initiated in state administrative and judicial fora. ${ }^{112}$ The Supreme Court's new emphasis on the background principles of state property and tort law may also prompt federal court abstention to

108. Justice Kennedy explained how both takings law and Fourth Amendment doctrine share "circularity" in judicial reasoning. In both, courts shape the private expectations (whether in property or privacy) that then form the boundary of constitutional protection. Lucas, 112 S. Ct. at 2903 (Kennedy, J., concurring).

109. Oliver v. United States, 466 U.S. 170, 179 (1984).

110. 483 U.S. 825 (1987).

111. 112 S. Ct. at 2902 n.18 (emphasis added).

112. See Williamson County Regional Planning Comm'n v. Hamilton Bank, 473 U.S. 172, 186-97 (1985); see also Thomas E. Roberts, Fifth Amendment Takings Claims in Federal Court: The State Compensation Requirement and Principles of Res Judicata, 24 URB. LAw. 479 (1992) (arguing that the ripeness rule essentially deprives property owners of the chance to litigate in federal court). 
provide state courts with the first opportunity to resolve those issues of state law. ${ }^{113}$

\section{CONCLUSION}

For well over a decade, a majority on the Supreme Court has accepted the premise that unduly harsh environmental restrictions warrant judicial redress through the Takings Clause. The Court has devoted considerable time to the takings issue, notwithstanding the absence of the kind of conflict in the lower court rulings normally necessary to trigger the Court's review. Yet, in most of the cases granted certiorari, the Court concluded that the constitutional challenge lacked merit. And, the precedential impact of those few instances in which the Court ruled for the property owner has been reduced by the thinness of the shifting coalitions that produced the result.

Lucas is no exception. The Court assembled a majority in favor of the private property owner only by relying on the fiction that the challenged law had diminished the value of the plaintiff's land essentially to zero. The more far-reaching and controversial implications of the majority opinion, authored by Justice Scalia, are unlikely to command a future majority. In particular, neither Justice O'Connor nor Justice White's successor seems likely to share Justice Scalia's belief in heightened judicial scrutiny of state legislative efforts to redefine private property in response to changing social conditions and empirical information.

Rather, Lucas likely signals the emergence of a takings analysis that is more receptive to environmental concerns. Even after accepting the fiction that no economic value remained in Lucas' property, the Court could not conclude that a taking had occurred. The Court ultimately acknowledged that the physical interaction among natural resources may justify the government's restriction of those private property rights without violating the Takings Clause. The Court also recognized, albeit parenthetically, the dynamic nature of permissible restrictions due to "changed circumstances" and "new knowledge."

Of course, predicting future Supreme Court outcomes based on past performance is an uncertain enterprise. The Court is not monolithic; its views change along with its membership. Less obvious, but as important, the Court's views shift as its assumptions regarding the world around it change. The latter phenomenon likely explains the surprising emergence last Term of the triumvirate opinion joined by Justices Kennedy, O'Connor, and Souter in Casey, ${ }^{114}$ the Pennsylvania abortion case. At least two of the three Justices reconsidered their prior disparagement of Roe v. Wade, ${ }^{115}$ and decided to reaffirm its "essential holding." 116

113. Cf. Railroad Comm'n v. Pullman Co., 312 U.S. 496 (1941) (postponing resolution of a Fourteenth Amendment racial discrimination claim until the state court definitively construes a state statute).

114. 112 S. Ct. 2791 (1992).

115. 410 U.S. 113 (1973).

116. Casey, 112 S. Ct. at 2804. 
Perhaps a similar questioning of premises is now warranted on the takings issue. The most important lesson of the Court's decade-plus effort to limit environmental regulation through the Takings Clause may be that the effort is misguided. The Court's inability to develop a coherent, consistent framework for takings analysis is symptomatic of a deeper flaw in the Court's thinking. The Court has reason to reconsider its apparent underlying assumption that a serious problem exists warranting an extraordinary exercise of judicial intervention. As in past Terms, the governmental excesses anticipated in Yee and PFZ Properties failed to materialize on closer scrutiny. And in Lucas, the Court was able to rule for the landowner only by assuming that the government had deprived the land of any economic value, and by declining to scrutinize such an unlikely proposition. In short, the Takings Clause has not been reinvigorated because the Court has not discovered any widespread problem justifying that result. For this same reason, the Court should begin to question the wisdom of the entire takings venture. 